\title{
Urban Structure And The Spacing Of Cities: An Empirical Investigation
}

\author{
J. Kevin Hourihan* and Curtis C. Roseman**
}

\begin{abstract}
There is both empirical and theoretical evidence that the population size of urban centers is closely related to their spatial distribution. Population size involves considerably more than Christaller's concept of centrality: it includes basic and non-basic activity at the secondary, tertiary, and quaternary levels. Concepts based on transportation and administration principles and aspects of Loschian theory explain part of this relationship. To investigate the relationship between specific aspects of functional size and the distance separating cities, an exploratory model is tested in west-central Oklahoma. Ten orthogonal components explain most of the variance in a 35-variable matrix which embraces functional, demographic, social and surface characteristics of the urban system. Four distinct hierarchical levels exist in this area. Scores on the ten components are used to predict the distance separating cities from their nearest neighbors of similar or higher hierarchical levels. Almost 79 percent of the spacing variation is explained, with 68 percent of the total explained by two service-type components.
\end{abstract}

Central place theory is generally regarded as the only comprehensive model of city size and distribution patterns. Since the extension of the Christaller-Losch theory by Isard (1956) and Berry and Garrison (1958), most analytic studies of the spatial distribution of cities have been developed within its framework. The theory has been used, and subsequently discarded, as a model of intra-urban tertiary activity (Berry, 1967, 1971), and as a framework for testing growth pole theory (Odland, et al., 1973), and it is presently undergoing theoretical reformulations to incorporate a dynamic aspect (White, 1974). Still, it is the theory of urban size-spatial relationships which is of most importance to geographers.

The purpose of the present research is to propose and test a more comprehensive model of city spacing than has hitherto been derived. We show that there is a theoretical basis for examining the relationship between several economic sectors of an urban system and its spatial characteristics. The model derives basic dimensions of an urban system

\footnotetext{
*University College, Cork, Ireland.

**University of Illinois at Urbana-Champaign.
} 
via principal components analysis, and relates these dimensions to the distances separating cities, within a hierarchical framework.

\section{Previous Research}

Analyses of the spacing of urban centers have been operationalized in several ways. In one approach, groups of cities have been treated as dimensionless points on featureless surfaces, and analyzed with nearestneighbor techniques devised to identify regularity and randomness, and to assess the extent to which each exists through measures of system entropy. ${ }^{1}$ Alternatively, surface disparities may be controlled through topological transformations in attempts to approximate the isotropic surface of classical central place theory (Rushton, 1972). These approaches have a number of drawbacks. Some ignore the size of the cities under analysis, thereby removing one important aspect of central place theory. Others depend on the accurate identification of hierarchical levels - although this is quite difficult to achieve - and different results have been found using different techniques. ${ }^{2}$ Moreover, all of the techniques are based on the triangular lattice of Christaller's $\mathrm{K}=3$ system. Theoretically, this pattern will emerge only through the exclusive operation of the marketing principle, although it is doubtful that this exists in isolation anywhere at present. Concepts based on transportation and administration principles and the Loschian structure have not been incorporated in these studies.

Another approach to distinguishing spacing regularities is that proposed by Thomas (1961) in his "expanded central place model." Thomas hypothesized a positive relationship between population size and the distance separating settlements of similar size, treating both variables as continuous rather than discrete. The model was operationalized through linear regression of the form: $d=L(s)$ where $d$ is distance, $s$ is population size, and $\mathrm{L}$ is a linear function with positive slope. This was subsequently extended by King (1961) to include other characteristics of the urban centers and aspects of the surface under analysis, in attempts to isolate "noise" from the model. A later test in Ireland also showed promising results (O'Farrell, 1970).

However, although the model is described as an "expanded central place" framework, it is not a test of classical central place theory. Relaxing the assumptions of discrete hierarchical levels and "typical" distances is necessary for testing the relationship, and is more in accord with reality. The independent variable, population size of settlements, was not suggested as a surrogate for centrality, but rather as a heuristic extension of the model. Christaller (1966, p. 17) was careful to distinguish between a city's population size and its centrality, or basic tertiary activity. Several indices have been developed to measure this, including Christaller's (1966, p. 147) telephone index. ${ }^{3}$

Population size includes considerably more than Christaller suggested: even in cities which function solely as service centers, it includes that 
proportion of the population engaged in non-basic activity, and in most cities it includes persons engaged in the secondary and quaternary sectors, and possibly reverse commuters working at primary activity, as well as the aged and unemployed. However, Thomas' model empirically validates the relation between an aggregate measure of all sectors of the economy of cities and the distance separating them.

\section{Urban Structure and Spacing: An Exploratory Model}

While Christaller provides a theoretical basis for anticipating a relationship between the distance separating cities and the population employed at basic service activity in them, there is also a rationale for including the work force in transportation and administration in the independent variable. Given the relaxation of the rigid hierarchical and geometric structure used by Thomas, there is certainly a relationship between these sectors and spacing in the $\mathrm{K}=4$ and $\mathrm{K}=7$ systems. Moreover, many writers have suggested that the Loschian pattern is more suited to secondary activities than to tertiary ones (von Boventer, 1963,) so there may also be some tenuous relationship between distance and certain industries which locate independently of functional agglomerative forces. This argument has been recently extended by Parr (1973). He argues that classical "central place theory can be concerned with economic activity of an intermediate type such as wholesaling, transportation, specialized banking and finance", and with certain types of manufacturing activity. The crucial restriction, according to Parr, is that this activity be of a "market-oriented or market-sensitive nature." City location, as King (1961) noted, does not occur on an isotropic surface, and any predictive model must incorporate real-life variations in population density, income, primary industry, and other variables which may affect the spacing of cities. Thus, one might visualize an additive model which embraces both the different aspects of population size and different types of surface. Christaller has shown, under simplifying assumptions, that a triangular lattice of service centers will develop on an isotropic income and density surface. Variations in these surface variables may be expected to affect the spacing of the service component. Similarly, variations in transport network density should affect the spacing of the transportation sector of the economy of cities, and the distribution of raw materials will influence the secondary sector

Our approach is to examine the relationship between the various components of population size and surface variations and the distance separating settlements. Past studies have shown that urban systems may be decomposed into a number of basic additive dimensions. According to Ahmad (1965) "it seems that five factors - size, the specific set of economic specialties, population change, density, and some social characteristics such as income and literacy - are sure to emerge as independent differentiating elements of urban systems in any situation." 
Thus, although any urban system comprises many economic sectors, dynamic aspects, locational influences and social connotations, ${ }^{4}$ the number of underlying dimensions is relatively small.

The present study will decompose a system of cities into its basic dimensions. These dimensions should provide a comprehensive statement of the system's economic specialties, dynamic and locational orientations in relation to the surface on which it is located - which should explain the spatial distribution of the constituent cities. To test this, a hierarchy will first be derived by cluster analysis. Then, within a hierarchical framework, the basic dimensions will be used as predictors for the distance separating cities of the system. This should provide a clearer insight into the nature of city spacing than has hitherto been achieved, and, if successful, would permit the development of inductive theory.

\section{The Operational Model}

The 35 variables used as indices of size and surface composition are shown in Table 1 . These are broadly related to several different concepts: population size and growth, social aspects, functional emphases, and location. An additional concept is concerned with relevant surface characteristics: these variables were measured at county level for each of the cities under analysis.

In choosing a study area in which to test the model, a city system, or subsystem, is an important requirement. This is to ensure that the spatial distribution of cities under study has developed independently, without undue influence from external forces. Ideally, a closed system, such as an island, is required, since, in an arbitrarily-defined study area, a city's nearest neighbor may lie outside the limits of the area, and distance to another city within the area may give misleading results. In the present study, a system of cities was identified in west central Oklahoma in the United States (Figure 1), using the maps prepared by Berry (1967). In terms of commuting patterns, urban fields, and functional orientation, this area is relatively self-contained, with very little overlap with nearby states. This area was treated as a closed subsystem for purposes of the analysis.

All cities and urbanized areas of not less than 2,500 population identified in the 1970 census were included in the study. This totalled 73 cities, ranging in size from Stroud $(2,502)$ to the urbanized area of Oklahoma City $(579,788)$. The mean population size was 22,925 . The area thus identified avoids extreme complexity or simplicity, but it does include an interesting range of growth and functional characteristics.

\section{The Latent Dimensions of the Oklahoma Urban System}

Principal components analysis was used to decompose the independent variables into their basic dimensions. This both reduces the number of 
TABLE I. THE VARIABLES AND THEIR CONCEPTUAL BASES

\begin{tabular}{|c|c|}
\hline Absolute Size & $\begin{array}{l}\text { 1. Population } 1970 \\
\text { 2. Labor force } 1970\end{array}$ \\
\hline Growth & 3. 1970 population as percentage 1960 population \\
\hline $\begin{array}{l}\text { Social } \\
\text { Correlates }\end{array}$ & $\begin{aligned} \text { 4. } & \text { Percent labor force female } \\
5 . & \text { Percent under poverty level } \\
6 . & \text { Per capita income } \\
\text { 7. } & \text { Percent under } 18 \text { years old } \\
8 . & \text { Percent aged } 65 \text { years and over } \\
9 . & \text { Fertility ratio } \\
\text { 10. } & \text { Persons per household }\end{aligned}$ \\
\hline $\begin{array}{l}\text { Marketing } \\
\text { Principle }\end{array}$ & $\begin{array}{l}\text { 11. Percent labor force in wholesale and retail trade } \\
\text { 12. Percent labor force in professional services } \\
\text { 13. Total retail establishments } \\
\text { 14. Annual retail sales } \\
\text { 15. Total food stores } \\
\text { 16. Total furniture, home furnishings, and equipment stores }\end{array}$ \\
\hline $\begin{array}{l}\text { Transportation } \\
\text { Principle }\end{array}$ & $\begin{array}{l}\text { 17. Percent labor force in transportation } \\
\text { 18. Scheduled airline stops } \\
\text { 19. Distance to highway }\end{array}$ \\
\hline $\begin{array}{l}\text { Administration } \\
\text { Principle }\end{array}$ & $\begin{array}{l}\text { 20. Percent labor force in public administration } \\
\text { 21. County seat }\end{array}$ \\
\hline $\begin{array}{l}\text { Industrial and } \\
\text { Resource Towns }\end{array}$ & $\begin{array}{l}\text { 22. Percent labor force in manufacturing } \\
\text { 23. Percent labor force in communications, } \\
\text { utilities, and sanitary services } \\
\text { 24. Percent labor force in finance, insurance, } \\
\text { business, and repair } \\
\text { 25. Percent labor force in educational services } \\
\text { 26. Percent 3-34 year olds in school } \\
\text { 27. Percent labor force in construction }\end{array}$ \\
\hline $\begin{array}{l}\text { Locational } \\
\text { Characteristics }\end{array}$ & $\begin{array}{l}\text { 28. Number of towns (over } 1,000 \text { ) within } 25 \text { miles } \\
\text { 29. Distance to a central city of over } 50,000\end{array}$ \\
\hline $\begin{array}{l}\text { Surface } \\
\text { Characteristics }\end{array}$ & $\begin{array}{l}\text { 30. Percent county population rural } \\
\text { 31. Per capita county rural income } \\
\text { 32. County rural population density } \\
\text { 33. Percent county rural labor force in primary industry } \\
\text { 34. Percent county area in farms } \\
\text { 35. Average county farm size }\end{array}$ \\
\hline
\end{tabular}

variables and eliminates "noise" from the system by isolating the variance-maximizing components. Ten components with eigenvalues greater than unity were rotated to orthogonal simple structure according to the normal Varimax criterion. Together, these ten components accounted for almost 83 percent of the original total variance, with the first four factors accounting for over half the original. Communalities, loadings greater than .4 and less than - .4, and component variances after rotation are shown in Table 2.

All of the components are interpretable in the context of the model to be tested. The first is a central services factor with very high positive 


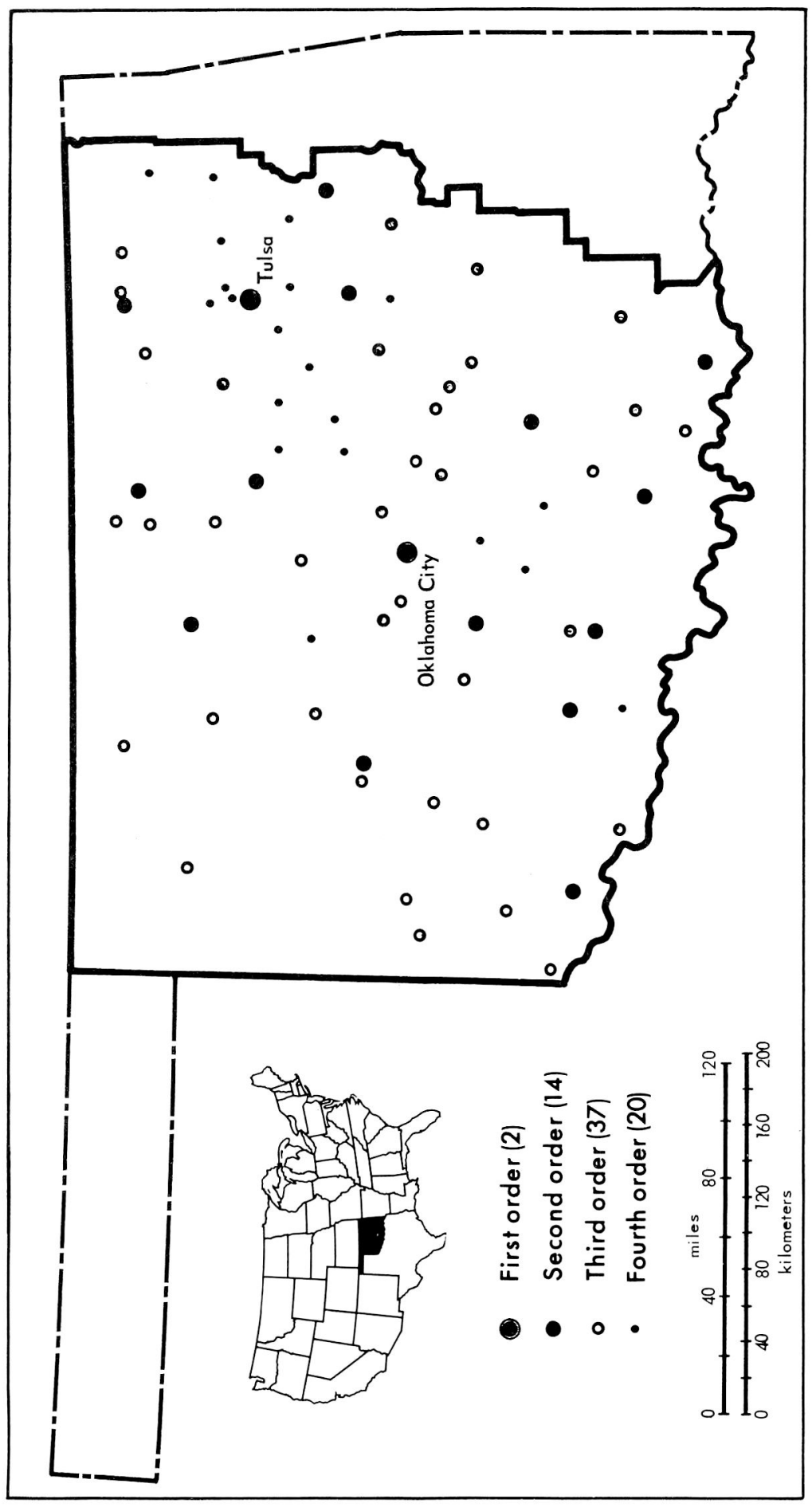

Figure 1. Hierarchy of Cities Within the Study Area 
TABLE II. ROTATED COMPONENT STRUCTURE MATRIX

\begin{tabular}{|c|c|c|c|c|c|c|c|c|c|c|c|c|}
\hline \multirow[b]{2}{*}{ No. } & \multirow{2}{*}{$\begin{array}{l}\text { VARIABLE } \\
\text { Short Title }\end{array}$} & \multirow[b]{2}{*}{$\mathbf{I}$} & \multirow[b]{2}{*}{ II } & \multirow[b]{2}{*}{ III } & \multicolumn{3}{|c|}{ COMPONENT } & \multirow[b]{2}{*}{ VII } & \multirow[b]{2}{*}{ VIII } & \multirow[b]{2}{*}{ IX } & \multirow[b]{2}{*}{$\mathrm{x}$} & \multirow[b]{2}{*}{$\mathbf{h}^{2}$} \\
\hline & & & & & IV & $\mathbf{V}$ & VI & & & & & \\
\hline 2 & Labor force & .984 & & & & & & & & & & .995 \\
\hline 13 & Retail establishments & .981 & & & & & & & & & & .996 \\
\hline 1 & Population & .980 & & & & & & & & & & .995 \\
\hline 14 & Retail sales & .980 & & & & & & & & & & .994 \\
\hline 15 & Food stores & .973 & & & & & & & & & & .989 \\
\hline 16 & Furniture stores & .971 & & & & & & & & & & .992 \\
\hline 28 & Towns within 25 miles & .652 & -.493 & & & & & & & & & .825 \\
\hline 32 & Rural population density & & -.876 & & & & & & & & & .890 \\
\hline 34 & Area in farms & & .848 & & & & & & & & & .812 \\
\hline 33 & Rural labor force in & & & & & & & & & & & \\
\hline & primary industry & & .836 & & & & & & & & & .818 \\
\hline 29 & Distance to city & & .650 & & & & & & & & & .738 \\
\hline 35 & Average farm size & & 639 & & & & & & & .569 & & .765 \\
\hline 5 & Under poverty level & & & -.858 & & & & & & & & .842 \\
\hline 31 & Rural income & & & .832 & & & & & & & & .792 \\
\hline 6 & City income & & & .716 & & & & & & & & .788 \\
\hline 8 & Aged 65 years and over & & & -.570 & & & -.429 & .484 & & & & .897 \\
\hline 10 & Persons per household & & & .550 & & .434 & & -.436 & & & & .943 \\
\hline 30 & Percent county population rural & & & -.520 & & & & & & & & .715 \\
\hline 26 & $3-34$ year olds in school & & & & -.872 & & & & & & & .798 \\
\hline 25 & Labor force in education & & & & -.820 & & & & & & & .863 \\
\hline 9 & Fertility ratio & & & & .819 & & & & & & & .804 \\
\hline 7 & Aged 17 years and under & & & .479 & .649 & & & & & & & .866 \\
\hline 20 & Public administration & & & & & .848 & & & & & .441 & .816 \\
\hline 3 & 1960-70 growth & & & & & .736 & & & & & & .803 \\
\hline 24 & Finance and insurance & & & & & & .832 & & & & & .850 \\
\hline
\end{tabular}


Table II (cont.)

\begin{tabular}{|c|c|c|c|c|c|c|c|c|c|c|c|c|}
\hline \multirow[b]{2}{*}{ No. } & \multirow{2}{*}{$\begin{array}{l}\text { VARIABLE } \\
\text { Short Title }\end{array}$} & \multirow[b]{2}{*}{ I } & \multirow[b]{2}{*}{ II } & \multirow[b]{2}{*}{ III } & \multicolumn{3}{|c|}{ COMPONENT } & \multirow[b]{2}{*}{ VII } & \multirow[b]{2}{*}{ VIII } & \multirow[b]{2}{*}{ IX } & \multirow[b]{2}{*}{$\mathrm{x}$} & \multirow[b]{2}{*}{$\mathbf{h}^{2}$} \\
\hline & & & & & IV & $\mathrm{V}$ & VI & & & & & \\
\hline 18 & Airline stops & .423 & & & & & .668 & & & & & .771 \\
\hline 21 & County seat & & & & & & .454 & & & .435 & & .817 \\
\hline 12 & Professional services & & & & & & & 709 & & & & .573 \\
\hline 17 & Transportation & & & & & & & -.486 & & & & .627 \\
\hline 4 & Female labor force & & & & & & & .410 & & & & .722 \\
\hline 11 & Wholesale and retail & & & & & & & & .835 & & & .831 \\
\hline 22 & Manufacturing & & & & & & & & -.691 & & & .808 \\
\hline 27 & Construction & & & & & & & & .421 & & & .664 \\
\hline 19 & Distance to highway & & & & & & & & & .835 & & .828 \\
\hline 23 & Communications & & & & & & & & & & .738 & .669 \\
\hline & Variance & 6.925 & 4.028 & 3.930 & 3.079 & 2.062 & 2.033 & 1.973 & 1.745 & 1.576 & 1.542 & \\
\hline & Percent total $\mathrm{v}$ & 19.78 & 11.51 & 11.23 & 8.80 & 5.89 & 5.81 & 5.64 & 4.98 & 4.50 & 4.41 & \\
\hline & Cumulative percent total variance & 19.78 & 31.29 & 42.52 & 51.32 & 57.21 & 63.02 & 68.66 & 73.64 & 78.14 & 82.55 & \\
\hline
\end{tabular}


loadings on population, labor force, and retail sales and establishments. This appears to be a general index of functional size, similar to that isolated by Berry $(1972$, p. 17). The second component serves to distinguish rural farm/non-farm differences. Percent of county area in farms and primary industry among the rural labor force have strong positive loadings, and rural population density loads negatively. Overall, this may be viewed as analogous to the surface characteristics used by King (1961) and others (O'Farrell, 1968, 1970). Towns with high scores on this component are those in the less urbanized western portion of the study area. The third factor indexes higher income towns in the more prosperous rural areas, and also correlates with several of the socialdemographic variables included in the analysis. Conceptually, this appears to be related to one type of surface-center interaction in the study area, especially that of income variation. A single aspect of urban function is identified by the fourth component. School enrollment and employment in education load negatively, while the fertility ratio loads positively. Component scores serve especially to identify college towns within the system.

The fifth component is again related to function, correlating positively with employment in public administration, and also with intercensal growth. The sixth dimension loads primarily on employment in the finance, business and insurance sectors. Medium-sized cities score highly on this component. To some extent it is an index of higher-order services. The seventh component is related especially to professional service employment, another sector of the economy. The eighth dimension is also related to function, reflecting the inverse relationship $(\mathrm{r}=-.47)$ between employment in trade and employment in manufacturing industry. Scores on this component index the primary focus of each center in this respect. The two remaining components each account for less than six percent of the common variance: the ninth correlates with distance from the interstate highway, and the tenth with employment in communications.

Together the ten dimensions form a comprehensive and detailed statement of each center's size, economic specialties, and surface characteristics, and appear to embrace all features of the system which might be related to spacing.

\section{The Urban Hierarchy}

Before proceeding with the test of the relationship between size and spacing, it is necessary to derive groups of cities. Thomas' model postulated a relationship between the size of each center and the distance separating it from its nearest neighbor of population size equal to, or greater than, itself. Such a test is not possible in the present case since each city is characterized by scores on ten dimensions. Therefore, we derive groups of cities which, hopefully, are hierarchical in nature, then 
use as the criterion the distance separating each city from its nearest neighbor of a similar or higher hierarchical level.

Using standard scores on each of the ten components, hierarchical groups were obtained by the use of Ward's (1963) clustering procedure. ${ }^{5}$ Distance measures in ten-dimensional Euclidean space were used to join cities in a pairwise fashion in order to minimize the objective function of within-group sums-of-squares. Grouping was terminated when no single city remained unallocated; at this stage the within-group sum-of-squares accounted for 76 percent of the total. Multivariate tests showed the four groups obtained to be significantly different (Tatsuoka, 1971). Wilks' likelihood-ratio criterion was $0.0042 .{ }^{6}$

The nature of the groups was examined by discriminant analysis, since it was necessary that functionally hierarchical groups be obtained. Three significant functions were obtained: the first two correlated strongly with components one and six (correlations are respectively -.782 and -.693). These components were originally interpreted as functional size and higher order functions, so it is clear that the clusters were functionally differentiated. A plot of the four groups on the two components shows the distinct clusters, and also their hierarchical ordering (Figure 2). Thus the four clusters were interpreted as levels on the urban hierarchy. Two first-order centers were identified: Oklahoma City and Tulsa. There were 14 second-order cities, 37 third-order and 20 fourth-order centers. It is clear that the fourth level was incomplete: the lower limit of 2,500 population necessitated by data availability probably truncated this group and eliminated the possibility of lower levels being included.

\section{City Spacing and the Urban Dimensions}

The distribution of cities of the four levels is shown in Figure 1. Straight-line distance in miles was measured between each city and its nearest neighbor of similar or higher hierarchical level. To some extent, "typical" distances are associated with each level (Table 3). These distances reinforce the interpretation of the groups of cities as hierarchical, since functionally lower centers should be separated by shorter distances.

Stepwise regression was used to test the relationship between distance and the component scores. Since the components are all related to size

TABLE III. HIERARCHICAL LEVELS AND MEAN DISTANCES

\begin{tabular}{crcc}
\hline Level & N & Mean & Std. Dev. \\
\hline 1 & 2 & 109.0 & - \\
2 & 14 & 42.29 & 11.79 \\
3 & 37 & 19.14 & 9.57 \\
4 & 20 & 14.90 & 5.59
\end{tabular}




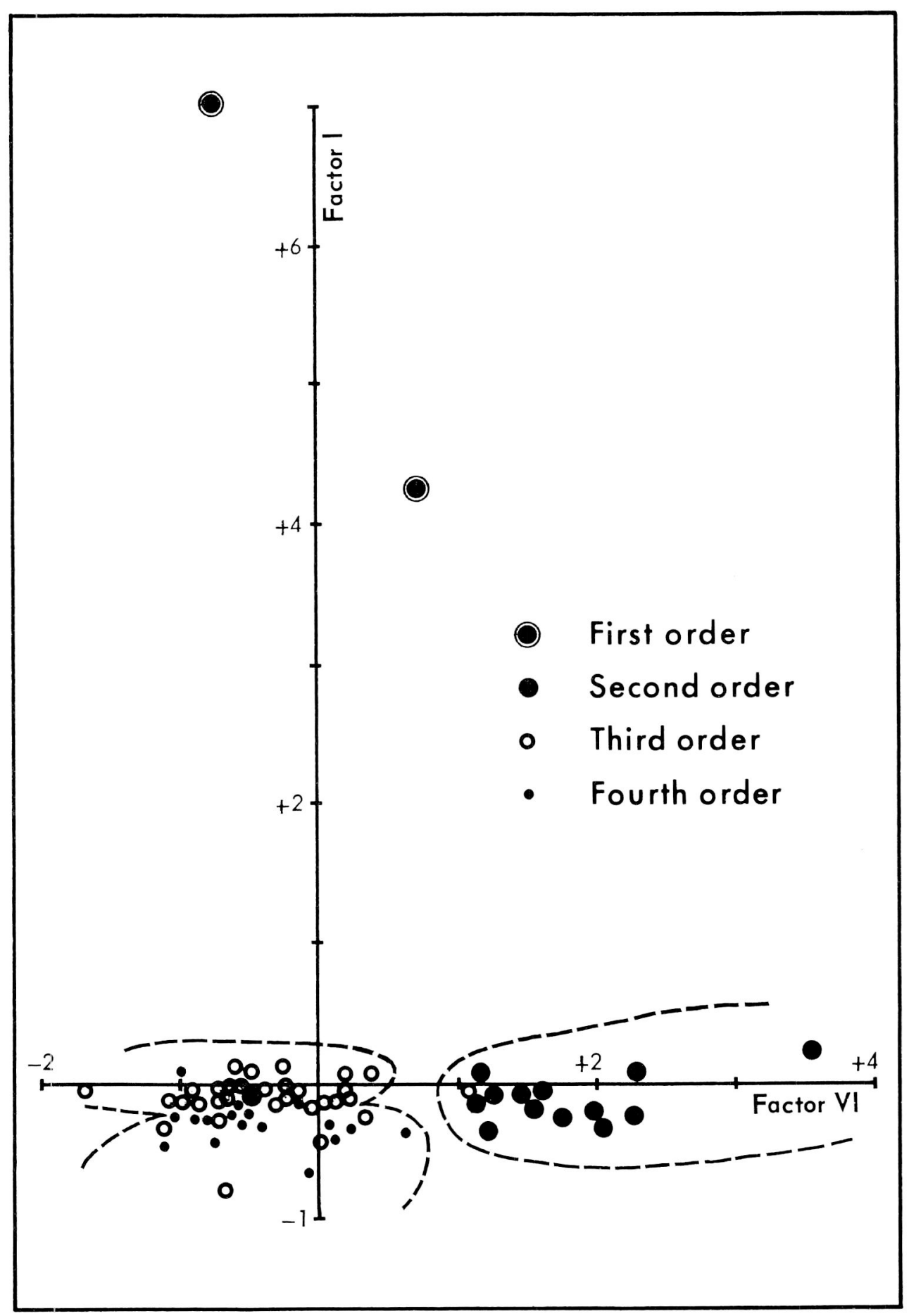

Figure 2. Clusters of Cities with Regard to Components I and VI 
TABLE IV. STEPWISE REGRESSION ANALYSIS

\begin{tabular}{|c|c|c|c|c|}
\hline \multicolumn{2}{|l|}{ Variable } & \multicolumn{2}{|c|}{ Definition } & Transformation \\
\hline \multicolumn{2}{|c|}{ Dependent } & \multicolumn{2}{|c|}{$\begin{array}{l}\text { Distance in miles of a city from its } \\
\text { nearest neighbor of similar or higher } \\
\text { hierarchical level. }\end{array}$} & None \\
\hline \multicolumn{2}{|c|}{ Independent } & \multicolumn{2}{|c|}{$\begin{array}{l}\text { Scores of a city on each of ten ortho- } \\
\text { gonal factors derived from an R-mode } \\
\text { principal components analysis. }\end{array}$} & Standardized \\
\hline \multicolumn{2}{|c|}{$\begin{array}{l}\text { Multiple R } \\
\text { Multiple R Squared } \\
\text { Intercept Value } \\
\text { Std. Error of Est. }\end{array}$} & \multicolumn{2}{|l|}{$\begin{array}{r}0.8884 \\
0.7892 \\
25.2599 \\
9.7301\end{array}$} & \\
\hline $\begin{array}{c}\text { Order of } \\
\text { entry }\end{array}$ & $\begin{array}{l}\text { Variable } \\
\text { Entered }\end{array}$ & Coefficient & $\begin{array}{c}\text { Multiple R } \\
\text { Squared }\end{array}$ & $\begin{array}{l}\text { Increase in } \\
R \text { Squared }\end{array}$ \\
\hline 1 & 1 & 14.0378 & 0.5077 & 0.5077 \\
\hline 2 & 6 & 8.2281 & 0.6827 & 0.1750 \\
\hline 3 & 4 & -3.8136 & 0.7203 & 0.0376 \\
\hline 4 & 9 & 3.3210 & 0.7488 & 0.0286 \\
\hline 5 & 8 & 2.8943 & 0.7705 & 0.0217 \\
\hline 6 & 3 & 2.1726 & 0.7827 & $0.0122 *$ \\
\hline 7 & 2 & 1.4760 & 0.7883 & $0.0056^{*}$ \\
\hline 8 & 5 & -0.5445 & 0.7891 & $0.0008^{*}$ \\
\hline 9 & 7 & -0.1881 & 0.7892 & $0.0001 *$ \\
\hline 10 & 10 & -0.1301 & 0.7892 & $0.0000 *$ \\
\hline
\end{tabular}

*Not significant at the .05 level.

or surface characteristics, a strong relationship was hypothesized, with each dimension contributing additively to the level of explanation achieved. ${ }^{7}$ The results are shown in Table 4 . The first predictor to enter the equation is the central services factor, which accounts for half the variation in the distance variable. This level of explanation is comparable to the results of past studies using both population size and central services as predictors (Thomas, 1961; O'Farrell, 1968). The sixth component, which identified higher-order services and accounted for only 5.8 percent of the original variance in the data matrix, explains an additional 17.5 percent of the spacing variation. However, the only other independent variable to explain as much as three percent is the fourth component, which identified college towns. With all ten variables included, the explanatory power of the model is almost 79 percent.

The best predictor appears to be the functional size of each center. This is directly analogous to Christaller's importance-centrality concepts in the marketing system, so there is a strong theoretical basis for this relationship. The second variable - the finance and business factor explained a significant amount of variation in distance, without a strong 
theoretical basis, since, although it does include tertiary functions, it is primarily quaternary-level activity. Its association with distance may be a widespread phenomenon, or it may be limited to the present study area. Alternatively, other specific sets of functions may replace it in other areas. The third factor to enter the equation is interesting, although its explanatory powers are low. This is the educational function, which should theoretically have no relationship to distance, but its inclusion in the regression model for the Oklahoma system proves otherwise. The fourth variable, component nine, indexes the growth associated with accessibility to the interstate highway system. To some extent this may be interpreted as a $\mathrm{K}=4$ type variable. The failure of the second and third components - the surface-type dimensions - to achieve some explanation is surprising. It was expected that these would operate to remove surface distortions which affected function-spacing relationships. This may be due to the relative smallness and homogeneity of the study area, or to the variables chosen to operationalize the concept.

\section{Conclusions}

Overall, this approach to the analysis of city spacing patterns appears promising. The use of components analysis to decompose the functional size and surface characteristics of an urban system into its basic dimensions provided deeper insight into the system than would be available otherwise. The use of cluster analysis to obtain a functional hierarchy was validated, and the regression model was quite powerful. The relationships revealed by the model included both conventional and innovative relationships. The predictive power of the central services component was expected, while that of the higher-order service and educational functions has not been shown before. Moreover, King (1966) has shown the stability of dimensions of this type over time, so longitudinal studies of component-spacing relationships should be feasible. This may afford insight into dynamic aspects of spacing.

On the other hand, the model also shows the need for finer calibration, involving the use of more detailed employment data, in order to identify economic sub-sectors which are related to distance (Parr, 1973). Given this, and replication in different areas, this approach may produce inductive generalizations about the spacing of cities which could contribute substantially to urban theory.

\section{FOOTNOTES}

1For nearest-neighbor analyses of city spacing, see, for example: King (1962) and Dacey (1962). Measures of system entropy are used in Medvedkov (1967), and Semple, et al. (1970).

$2 \mathrm{As}$ a case in point, the hierarchy identified by Brush (1953) in southwestern Wisconsin has been analyzed by Dacey (1962) by nearest-neighbor methods and through entropy techniques by Medvedkov (1967). Conflicting results were obtained. For a discussion of hierarchies, see Davies (1966) and Marshall (1969).

${ }^{3}$ See, for example, the indices developed by Olsson, et al. (1963) and Davies (1965).

4 For discussions of the social correlates of city size, see Schnore, et al. (1955) and Hawley (1971, pp. 135-138). 
$5 \mathrm{~A}$ distinction is required between the functionally hierarchic groups obtained and the hierarchic clustering algorithm itself. Taxonomically, the algorithm is hierarchic since successive clusters are obtained by the merging of previous clusters. For a discussion, see Johnson (1967).
${ }_{6}$ Bartlett's chi-square approximation of lambda for overall significance was 355.749 with 30 degrees of freedom. This is significant at the .001 level.

7 Since the components are orthogonal, the regression model is truly additive. Multicollinearity has been a problem in previous studies: see, King (1961) and O'Farrell (1970).

\section{REFERENCES}

Ahmad, Q. (1965), Indian Cities: Characteristics and Correlates, Research Paper No. 102 Department of Geography, University of Chicago.

Berry, B. J. L. (1967), Geography of Market Centers and Retail Distribution. Englewood Cliffs, New Jersey: Prentice-Hall.

(1967), Maps prepared for the Social Sciences Research Council. (1971), "The passing of central place theory." In: R. A. Leetsma, Research Institute Lectures on Geography, Virginia: U. S. Army Engineer Topographic Laboratories.

Berry, B. J. L., and W. L. Garrison (1958), "Recent developments of central place theory." Regional Science Association, Papers and Proceedings, 4, p. 107-120.

Brush, J. E. (1953), "The hierarchy of central places in Southwestern Wisconsin." Geographical Review 43, p. 380-402.

Christaller, W. (1966), Central Places in Southern Germany. Englewood Cliffs, New Jersey: Prentice-Hall.

Dacey, M. F. (1962), "Analysis of central place and point patterns by a nearest-neighbor method." Lund Studies in Geography, Series B, 24, p. 55-75.

Davies, W. K. D. (1965), "Some considerations of scale in central place analysis." Tijdschrift voor Economische en Sociale Geografie 56, p. 221-227.

(1966) "The ranking of service centers: a critical review." Institute of British Geographers, Transactions 40, p. 5165.

Hawley, A. H. (1971), Urban Society. New York: Ronald Press.

Isard, W. (1956), Location and Space-Economy. Cambridge: M.I.T. Press.

Johnson, S. C. (1967), "Hierarchical clustering schemes." Psychometrika 32, p. 241-255.

King, L. J. (1961), “A multivariate analysis of the spacing of urban settlements in the United States." Annals, Association of American Geographers 51, p. 222-234.

(1962), "A quantitative expression of the pattern of urban settlements in selected areas of the United States." Tijdschrift voor Economische en Sociale Geografie 53, p. 1-7.

(1966), "Cross-sectional analysis of Canadian urban dimensions: 1951 and 1961." Canadian Geographer 10, p. 205224.

Losch, A. (1954), The Economics of Location. New Haven: Yale University Press.

Marshall, J. U. (1969), The Location of Ser- vice Towns. Toronto: University of Toronto Press.

Medvedkov, Yu. V. (1967), "Concept of entropy in settlement pattern analysis." $R e^{-}$ gional Science Association, Papers and Proceedings 18, p. 165-168.

(1968), "An application of topology in central place analysis." Regional Science Association, Papers and Proceedings 20, p. 77-85.

Odland, J., E. Casetti, and L. J. King (1973), "Testing hypotheses of polarized growth within a central place hierarchy." Economic Geography 49, p. 74-79.

O'Farrell, P. (1968), "A multivariate analysis of the spacing of central places in County Tipperary." Irish Geography 5, p. 428-440. (1970) "A multivariate model of the spacing of urban centers in the Irish Republic." In: N. Stephens and R. E. Glasscock (Eds.), Irish Geographical Studies in Honour of E. Estyn Evans, Belfast: The Queen's University of Belfast.

Olsson, G., and A. Persson (1963), "The spacing of central places in Sweden." Regional Science Association, Papers and Proceedings 12, p. $87-93$

Parr, J. B. (1973), "Growth poles, regional development and central place theory." Regional Science Association, Papers and Proceedings 31 , p. 173-212.

Rushton, G. (1972), "Map transformations of point patterns: central place patterns in areas of variable population density." $R e$ gional Science Association, Papers and Proceedings 28, p. 111-129.

Schnore, L. F., and D. W. Varley (1955), "Some concomitants of metropolitan size." American Sociological Review 20, p. 408-414

Semple, R. K., and R. G. Golledge (1970), "An analysis of entropy changes in a settlement pattern over time." Economic Geography 46, p. 157-160.

Tatsuoka, M. (1971), Multivariate Analysis New York: John Wiley and Sons.

Thomas, E. N. (1961), "Toward an expanded central place model." Geographical Review 51, p. 400-411.

von Boventer, E. (1962), "Towards a united theory of spatial economic structure." Regional Science Association, Papers and Proceedings 10 , p. 163-188.

Ward, J. H. (1963), "Hierarchical grouping to optimize an objective function." Journal, American Statistical Association 58, p. 236243.

White, R. W. (1974), "Sketches of a dynamic central place theory." Economic Geography 50 , p. $219-228$ 